R. N. SOFFER

\title{
ATTITUDES AND ALLEGIANCES IN THE UNSKILLED NORTH, I83O-I850
}

In the Northern textile areas of Yorkshire and Lancashire, the unskilled laborer's hostility to the new industrial middle classes ${ }^{2}$ led him to Chartism but not to class-consciousness, the recognition that his interests differed not only from the middle classes but from the upper classes as well. ${ }^{3}$ The unskilled workingman's antagonism to the

1 A great gulf existed between skilled factory laborers, those in stable industries, and unskilled handicraft workers who competed unsuccessfully with factory machinery in Yorkshire and Lancashire and turned in despair to Chartism during the 'thirties and 'fortics. Class consciousness developed only in areas like the Northeast and London or Birmingham where large numbers of skilled workers benefitted from industrialization and identified their future with the development of industry. See W. H. Maehl, "Chartist Disturbances in Northeastern England, 1839", in: International Review of Social History, Vol. 8, Part 3, 1963, pp. 389-414; R. C. O. Matthews, A study in Trade-Cycle History: Economic Fluctuations in Great Britain, 1833-1842 (Cambridge University, 1954), particularly pp. 144, 148, 22 I and, N. Smelser, Social Change in the Industrial Revolution (University of Chicago, 1959). Smelser on Pp. 245 and 26 If. discusses the relationship between handloom weavers, the industrially unskilled, and the factory operatives in the skilled, more stable factory industries: "In the late 1830 's and early 1840 's... the spinners' and other factory operatives' involvement in social explosions was limited... One important reason for this is that the factory operatives were gradually approaching the completion of a sequence of differentiation... [and] entering the industrial era on a new basis. By contrast... the weavers and related groups were gasping for their very life." (p. 245).

2 The term "new industrial middle classes" or "industrial middle classes" will be used in this paper to designate the interests whose wealth grew in the Northern industrial areas either from the ownership of factories, from control of handicraft industries, or from some related economic function dependent on industrial society. Although imprecise, this term is useful to describe a large group with varied incomes, though generally wealthy, who held common attitudes formulated for them by the political economists. See G. Kitson Clark, The Making of Victorian England (London, 1962), pp. 5-75, and A. Briggs, "The Language of 'Class' in Early Nineteenth-Century England", in: Essays in Labour History (London, 1960), pp. 52-60.

3 In his "Local Background of Chartism", Chartist Studies (London, 1959), p. 12, Asa Briggs argues that there "were to be many firtations between Tories and Chartists in the future, but from the spring of 1838 onwards it was abundantly clear that Chartism would depend on its own leaders and not on alliance with people outside its ranks". This may be said of the small group of Radicals who devised and supported the Charter to secure political rights, but it is not applicable to the great numbers of confused workingmen in 
middle classes did not depend upon developing feelings of working class solidarity nor was it directed towards the older rural gentry. When the unskilled worker reacted against the middle classes in the I 830's and '40's he was not yet prepared economically or psychologically for independence or class action. ${ }^{1}$

In Yorkshire and Lancashire, at least, the unskilled worker's resentment of the industrial middle classes cannot be separated from his idealized memory of paternal government and his nostalgia for a pre-industrial past. ${ }^{2}$ His distrust of utilitarian ideology and middle class industrialization was so intense that he tended to ignore the sincere and often successful attempts of middle class reformers to cope with working class problems. He listened instead to paternalistic tory reformers who tried to persuade him that the fundamental interests of the tory gentlemen were as opposed to the triumph of industrialization as his own.

During the 1830 's and ' 40 's, insecure workers in the North accepted the lead of tories for three reasons: First, tories and workers both were unwilling to admit that the innovating middle classes had altered traditional definitions of security; second, Northern tories developed a comprehensive social theory which guaranteed the security, if not the progress, of labor; and finally, the tory tried to effect his social philosophy by advocating factory reform, by opposing the New Poor Law and by leading Chartism to the rural utopianism which many Northern workers identified with security. This paper argues that

the Northern textile areas of Yorkshire and Lancashire who sought immediate economic goals and chose political pressure only as an expedient means to alleviate economic problems. In "Chartism Reconsidered", in: Historical Studies (London, 1959), p. 56, Professor Briggs suggests that Chartist ideas lacked appeal in agricultural areas like Kent and Hampshire because "a social framework which depended on ... 'deference' existed" there. It may be argued that this same deference permeated industrial areas, too.

1 In The Trades Union Congress, I869-1921 (London, 1958), p. I3, B. C. Roberts points out quite rightly that the key to the success of trade unions after 1850 lay not only in the development of a highly industrialized society but in "the acceptance by the unions of the fundamental tenets of this society". Until his basic attitudes were changed, the Northern unskilled worker sought escape from an industrialized world rather than control over it.

${ }^{2}$ In a recent book, The Making of the English Working Classes (New York, I 964), E. P. Thompson sees in the Radical movements of the 1820 's origins of working class consciousness in which "working people come to feel an identity of interests as between themselves and as against their rulers and employers", p. I I. But although he describes the Radicals competently, Mr. Thompson mistakenly treats this small, self-educated and skilled minority as if it were the same as the great majority of "working people". Unlike the Radicals, the mass of workingmen, particularly in the industrial North, were not class conscious, and through the 'thirties and 'forties they remained uneducated, inarticulate, unskilled, and unaware of any "identity of interests as between themselves" (p. Ir). For Thompson's treatment of his thesis see especially Pp. I I-r 3, r 4I, and 7II-7I4. 
workingmen's receptivity to tory paternalism was determined more by the attitudes they held than by the actual circumstances which determined their condition. Many middle class humanitarians participated in the struggle for factory reform, Poor Law repeal and Chartism. In Parliament, certainly, the Whigs were better reformers than the Tories. ${ }^{1}$ Yet, in spite of this evidence, Northern laborers were hostile to the middle classes and their Whig representatives in Parliament. ${ }^{2}$ An important distinction exists between the way the displaced worker saw middle class reformers and the actual achievements of middle class reform. ${ }^{3}$

The first factor which drew industrial workers and rural tories together in Lancashire and Yorkshire was their common resentment of the new middle classes. ${ }^{4}$ The vast acceleration in daily life after the Napoleonic Wars led most people to feel that they had been living the

1 The Tories in Parliament during the 1830 's, and particularly during the '40's, cannot be treated as a homogeneous group. Nearly half of the representatives of business interests in Commons between 1841-1847 were Conservatives. The landed tories, identified with rural intercsts and social reform, were an entirely different group than the business interests who followed Peel. Cf. W. O. Aydelotte, "The House of Commons in the I840's", in: History, XXIX (Oct. I954).

2 When the Whigs were in power between I846-1854 they increased the paternalistic role of the central government far more than the Tories had done. (See D. Roberts, "Tory Paternalism and Social Reform in Early Victorian England", in: American Historical Review, LXIII, I: Jan. 1958.) But while the evidence against the Tories in Parliament may be damning it was even worse for the Whigs as the Northern worker saw them. The reforming activity of the Whigs only began late in the '40's with the Ten Hours Act of 1847 , a measure popularized by Northern tories and strenuously advocated by a Tory in Parliament, Lord Ashley. By then, the workingman had long identified repression and Whigs. Even when more Whigs than Tories entered the Opposition against the New Poor Law of 1834 , Tory social reformers in the North, who championed its repeal, succeeded in associating the measure with Whig-Liberal, middle class utilitarianism.

3 This paper will not discuss middle class social reform because it was not genuinely appreciated by the great majority of unskilled workers in Lancashire and Yorkshire, but will focus instead on the common attitudes which drew unskilled workers and tories together in the North.

- There were rural Whigs in the North, like the third Earl Fitzwilliam, who were as concerned as the tories to protect their landed interests against the newer industrial interests. But unlike the tories they did not respond to this threat by encouraging working class protest against the new middle classes. (See F. M. L. Thompson, "Whigs and Liberals in the West Riding, I830-1860", in: English Historical Review, LXXIV, 281; April, I 959). And, in Leeds, working class Radicals disavowed Edward Baines, the Leeds Mercury and the Whigs in 1829 because Baines and his paper championed industrialists. Unable to act alone, the Leeds Radicals formed a Tory-Radical alliance as a political strategy. See Harrison, "Chartism in Leeds", in: Chartist Studies, PP. 66ff. 
life of several centuries in one generation. Neither the rural tory nor the unskilled worker benefitted from this rapid development and they turned away from further change to idealize the past. Neither was able to adjust to an industrialized order which made them anonymous and dispensable. Moreover, they could not be convinced that industrialism was an adequate way of life or that laissez-faire individualism would best solve individual and social problems.

The unstable economic and social conditions in the North compelled most workers to reject the theories of linear progress insisted upon by the liberal middle classes. Many workingmen found that they were a limited and dispensable part of industrial processes. Instead of the promised long-range progress of the liberals, the Northern unskilled worker wanted an immediate remedy for the iniquities of industrialization. He preferred the kind of predictable life typical in a rural society because a real lack of economic security made it difficult to anticipate that industrial progress would include him. ${ }^{1}$ How could he accept the unknown direction of "progress" in which he did not share? Instead unskilled workingmen responded to leaders who promised simple solutions to the complex problems raised by industrial life.

When the unskilled worker in the textile areas accepted Chartism he did not accept working class leadership as did the more skilled and independent workingmen in London and Birmingham. The unskilled in Lancashire and Yorkshire welcomed another "gentleman" leader, Feargus O'Connor, and another panacea, Chartism. ${ }^{2}$ O'Connor's leadership of Northern Chartism was built upon tory success in persuading workers to rely upon external leadership instead of developing ideology and tactics of their own. ${ }^{3}$ O'Connor starred in a role written out for him in advance by Michael Sadler, Richard Oastler,

1 R. C. O. Matthews, in comparing money, wage rates and the cost of living from I $830-$ 1842 , concludes that the hand loom weaver was the most depressed of the working class groups. In 1839 and 1840 , the hand loom weaver earned only $75 \mathrm{~d}$. per week as compared to the agricultural worker's $80 \mathrm{~d}$. and the cotton operative's I I $2 \mathrm{~d}$. A Study in Trade-Cycle History, p. 221.

2 As W. H. Maehl points out in "Chartist Disturbances in Northeastern England, 1 839", Chartism in Newcastle, Sunderland, and the surrounding areas of Northumberland and Durham was of an entirely different nature. In the Northeastern areas Chartists followed Radical leadership and were more concerned with politics than economics. In December, 1839, General Napier wrote to Phillips of conditions in the Northeast: "it was for their political rights they were struggling and quite unconnected with the question of wages, respecting which they had no complaint to make." Quoted by Maehl, p. 413, from $H$. O. $4 \% / 53$, ff. $853-54$.

3 The continuing peasant mentality of the unskilled worker was shown by his enthusiastic response to return-to-the-land plans. Feargus O'Connor's abortive land scheme attracted 70,000 subscribers in the ' 40 's, almost in direct competition to the political program of the Charter then in preparation. See J. McAskill, "Chartist Land Plan", in: Chartist Studies: 
Parson George Stringer Bull and Joseph Raynor Stephens, the tory social reformers in the North. ${ }^{1}$ Although avowedly a Radical, O'Connor shared tory prejudices and assumptions. ${ }^{2}$ But while he did admit the need for political reform, his ultimate solution for workingmen's problems was a return to a simpler life on the land. O'Connor's radicalism was always supplemented by his pose as a landed gentleman of aristocratic family. ${ }^{3}$ The working class leaders of Chartism, like William Lovett in London, were rejected in much of the unskilled North because the laborer there could not be persuaded that he had more in common with skilled workers than with the gentry.

The paternalism of the tory social reformers re-enforced the worker's willingness to believe that his failure to find security in industrial life was due to the criminal irresponsibility of the middle classes and their Whig representatives in Parliament. The tory social theorists gave Northern Chartism, despite its ostensible purpose of political reform, an explanation for the displacement of industrial life based on a theory of middle class culpability. Political reform was not an end in itself for the Northern worker but a means of waging war upon those local middle class interests who controlled handicraft industries, as well as factories, and upon their spokesmen in Parliament. The political-minded Chartist leaders could not convince the Chartist rank and file in the North that they would achieve their ends through an alliance with sympathetic middle class Radicals like Thomas Atwood, or Joseph Sturge. ${ }^{4}$

"The Chartists shared with many Tories a powerful sense of the recent past. Fur them... industrial England had been created by tearing a section of her people from their roots" (p. 304).

1 The most perceptive study of Oastler specifically and of Northern Tory social reform in general remains Cecil Driver's Tory Radical (New York, 1946).

2 The Bradford Chartist John Jackson recognized that Fargus O'Connor has stepped into the vacuum in tory leadership in the North left by Oastler and he tried unsuccessfully to persuade the Chartist rank and file to find leaders among themselves. See Jackson's The Demagogue Done Up: An Exposure of the Extreme Inconsistencies of Feargus O'Connor (Bradford, 1844), in the Seligman Collection, Columbia University.

3 The standing which enabled O'Connor to become an M.P. and to lead the Chartist movement in the North came from his possession of Fort Robert, the estate of the O'Connors in County Cork. See D. Read and E. Glasgow, Feargus O'Connor (London, 1959), pp. 2 off.

4 See Carpenter's Can the Tories Become Reformers? (London, I 834), Seligman Collection, Columbia University; T. Clark's Reflections Upon the Past Policy and Future Prospects of the Chartist Party (London, I 8 50); W. J. Linton's Threescore and Ten Years, 1830-1 890 (New York, I894); Wm. Lovett's Letter to Messrs. Donaldson and Mason Containing His Reasons for Refusing to be Nominated Secretary of the National Charter Association (London, Sept. 8, 1843), Seligman Collection. For a sympathetic account of the Birmingham Chartist movement, its middle class liberal leaders and its disintegration, see J. A. Langford's Century of Birmingham Life (London, 1868). 
Political leaders tended to dismiss the Northern worker's willingness to follow tory leadership as a desperate strategy for attacking the Whigs. They were disgusted with the short-sightedness of the rank and file for allowing their resentment of "indignities suffered at the hands of Whigs" to "shape their policy". It was occasionally true that "to spite the Whigs", as George Jacob Holyoke complained, "the Chartists gave their support to the Tories". "This happened in the general election of $184 \mathrm{I} .{ }^{2}$ Working-class resentment of the Whigs is a necessary but not sufficient explanation of the worker's continued reversion to upper-class leadership during the 1830 's and '40's.

To the Northern handicraft laborer, the middle classes were "outsiders", the group responsible for wantonly destroying the patriarchical relationship of the governing classes to the governed. ${ }^{3}$ The Anti-Corn Law League failed to unite the middle and lower classes in an attack upon the landed interest because the unskilled worker in the North was not sure that the interests of the landed gentry were in fact different from his. A minority of skilled workers were attracted to the League because it appeared to offer a more immediate solution to high prices than Chartism did. ${ }^{4}$ But the unskilled majority saw the

1 G. J. Holyoke, Sixty Years of an Agitator's Life (London, I 885), I, p. 85.

2 In the $184 \mathrm{I}$ election, O'Connor asked Chartists to support Tories because the Whigs had used their powers to deceive the people. See The Northern Star, May 29-June 26, I 841 . For a discussion of the election of I 841 see R. G. Gammage, History of the Chartist Movement (London, 1854), pp. 192-195; Read and Glasgow, Feargus O'Connor, p. 95. A Tory majority was returned to Parliament in 1841 , no Chartist secured a seat, and in the West Riding the Whigs who had held seats since 1832 were all replaced by Tories. In July, 1841 the Whig Morning Chronicle confirmed that "the Chartists, such as are voters, have almost to a man supported the Tories." Quoted in Ward, The Factory Movement, 1830-1855 (London, 1962), p. 227.

$s$ Even if the unskilled worker did not come to this conclusion by himself, he heard it over and over whenever he attended mass meetings supporting the Ten-Hours movement or protesting the New Poor Law. Abuse of the middle classes was the principal rhetorical device used by O'Connor and the other Tory social reformers in the North who approached social problems with the techniques of revivalist preaching. G. D. H. Cole, Chartist Portraits, p. 188. Radical leaders, too, played upon the relation between economic exploitation and Government: On November 2, 1833, the Poor Man's Guardian wrote, "The middle classes, or profit men are the real tyrants of the country. Disguise it as they may, they are the authors of our slavery for without their connivance and secret support no tyranny could exist. Government is but a tool in their hands to execute their nefarious purpose." Quoted in Briggs, "Chartism Reconsidered", p. 53.

- Cole, Chartist Portraits, p. $56 f$. Cooke Taylor welcomed the League not only because repeal of the Corn Laws would mean increased prosperity for workers and employers alike but because it ended the "dangerous and increasing chasm between the employers and the employed". See Notes of a Tour in the Manufacturing Districts of Lancashire (London, I 842), p. 283. Cooke Taylor's sympathy with the Northern worker was jaundiced by his political economy and he believed that the unskilled working man raised an "outcry... against factories to counteract the growing cry for the repeal of the corn-laws". Ibid., p. 249. 
League's activities as a diversionary tactic by the middle classes to distract national attention from the Charter. ${ }^{1}$ Moreover, many Chartists equated cheap bread and falling wages. ${ }^{2}$ Despite extensive and well organized attempts of the League to produce unity, it provoked Chartists to their most "violent class declarations" against the middle classes. ${ }^{3}$ In the North, the League succeeded only in widening the gap between the unskilled worker and the middle classes.

The worker's distrust of Whigs and middle class reformers was nurtured not only by tory rhetoric but by the bitterness of cumulative disappointment. The Reform Parliament had turned out to be much the same as its predecessor except that the Whigs had gotten "possession of the power which the Tories... lost". ${ }^{4}$ To the worker, this power seemed directed against him. The Whig Government reacted in fear to the worker's legitimate, traditional procedures to seek remedy of grievances by suspending habeas corpus and by passing sedition and treason laws. ${ }^{5}$ The Whigs destroyed trade unionism, accepted the punitive provisions of the New Poor Law of 1834 , and refused to provide the factory legislation which Northern factory and handicraft workers alike considered essential. The factory reform movement was significant to handicraft workers, not because they expected to benefit from it, but as a lost test case of every workingman's right to paternal government. ${ }^{6}$

The Northern worker's indictment of the Whig Government for representing only middle class interests was proved for him by the Whig's severity in upholding sentences passes on Dorset laborers in I 834 and Glasgow spinners in I $837 .{ }^{7}$ This was evidence to the Northern worker that the industrial middle classes, whom he had helped

1 Lovett complained, in 1838 , that one of the major factors separating middle and working class union for securing the Charter was that the Anti-Corn Law movement "naturally excited the belief of the Working Classes that the object aimed at was not so much the repeal of those unjust laws, as it was to frustrate their agitation in favor of political reform." Life and Struggles (London, 1876 ), p. 173.

2 L. Brown, "Chartism and the Anti-Corn Law League", in: Chartist Studies, p. 53.

3 A. Briggs, "Chartism Reconsidered", p. 53.

- Ch. Grenville, Memoirs, II (New York, I885), p. 414.

- The Frenchman Ledru-Rollin despaired of Whig measures as "worthy of the worst days of England - nothing for the people". A.A. Ledru-Rollin, The Decline of England, I (London, i850), p. 41 .

- Although the Ten Hours Act was passed finally by a Whig Government in 1847, it passed largely because many Tories voted for it, with the exception of Peel, in retaliation against the industrial middle classes responsible for the repeal of the Corn Laws. Hansard, 3rd ser., Vol. I., XC, pp, 819-821.

7 See F. C. Mather, Public Order in the Age of the Chartists (Manchester University, 1959), for a detailed development of this argument. 
bring to political power through demonstrations and mass marches in 1830 and 1831 , intended now to destroy him. A Birmingham speaker who attacked the Whigs for hostility to "the interests of the working classes, which exceeded that exhibited by the Tories", ${ }^{1}$ found a responsive audience. The majority of unskilled workers who became Chartists had not joined the trade union movement, but they were still affected by its failure. When George Loveless, a Tolpuddle "martyr", published his Victims of Whiggery in August, I 837, there was a sympathetic audience in the urban North ready to identify Whig oppression and middle class interests. ${ }^{2}$ Northern workers tended to agree, despite their other differences, that "everything wrong was "Whig"'. 3

The Northern laborer blamed the industrial interests and the Whigs not only for political repression but for the series of fluctuating business cycles and severe depressions which began in 1837 and coincided with rises in the price of wheat due to poor harvests. Those who suffered most were in handicraft industries, which provided a marginal existence even in good times. In desperation these hosiery workers, handloom weavers and wool combers in the North responded to the militant movement within Chartism. ${ }^{4}$

1 Quoted by A Briggs from Report of the Proceedings, 20 May 1833 in "Local Background of Chartism", in: Chartist Studies p. 20. In English Landed Society in the Nineteenth Century (London, 1963), p. 276, F. M. L. Thompson observes that the record of parliaments between 1832 to 1868 "was not conspicuous for its neglect of middle class interests." The main tenor of changes from 1832 was "to embody in law and institutions the requirements of that industrial economy in which by far the major part was played by the middle classes." Since a Whig Government was in office during most of the years from $1832-50$, it is scarcely surprising that working men identified that government and the middle classes. In The Demagogue Done Up: An Exposure of the Extreme Inconsistencies of Feargus O'Connor (Bradford, r 844), p. 8, the Radical John Jackson attacked O'Connor for presenting the Tories Oastler and Stephens as the only faithful friends of the people. Jackson accused $O^{\prime}$ Connor of making "Radicalism to consist of Whig abuse" (p. 8) with the result that the Liberal part of the middle class had been driven back to the Whigs by the "Tory-Chartists or O'Connorites" (p. 49). Wm. Lovett, Life and Struggles (London, I 876), p. I $7^{2}$.

"By 184 I the London centered "moral force" Chartists, unlike the increasingly "physical force" Northerners, were prepared to distinguish between the Whigs and the middle classes. The London National Charter Association, led by Lovett and Hetherington appealed for a "cordial union of the Middle and Working Classes" for political reform. In Lovett, Life and Struggles, p. 262. The Address further requested the middle classes not to set up a "counter agitation" for repeal of the Corn Laws, "generating distrust where we believe mutual benefit is intended" (p. 263).

3 J. Jackson, The Demagogue Done Up, p. 8.

4 Particularly from $1837-1842$, and during $1847-1848$, unskilled laborers in the North faced marginal wages, poor harvests, rising food prices and unpredictable periods of unemployment. In addition there was a heavy disease and death toll from industrial congestion. It is in these years that Chartism grows among the unskilled workers in the 
In the late I 830 's through the I 840's the unskilled worker's economic vulnerability led him to militant Chartism, the organized expression of his distrust of industrialization. When the middle class liberal Cooke Taylor came to Burnley in Lancashire during I 842, he found that the unskilled laborer there "united to [his] Chartism a hatred of machinery, which was far from being shared by the factory operatives". 'Taylor was committed to the principles of political economy and industrial growth, but he recognized that "every outbreak in Lancashire for the last fifty years can be distinctly traced to distress, arising from scarcity of employment and consequently of food." He perceived clearly the economic origins of Chartism: "modern Chartism [is] nothing more than the indistinct [cry] of natural suffering." 2 Even the political-minded Chartist leaders knew that the movement had few followers concerned primarily with political reform and that Chartism was essentially "a protest; we had no plan byond that."3

When the Annual Register defined Chartism in 1839 as "in fact an insurrection which is expressly directed against the middle classes", it was expressing a common view. ${ }^{4}$ The tory leaders of the Ten Hours Movement and the Anti-Poor Law crusade had emphasized consistently the opposed interests of masters and men. When these movements merged into Chartism, they brought the ideology of conflict with them. This ideology received wide publicity through Feargus O'Connor's Nortbern Star, the most widely read periodical in the North, notorious for its abuse of the middle classes.

The Northern tory's rejection of the middle class and his leadership of working class social reform were both humanitarian and selfish. Despite their firm roots in the land, tories had become as insecure as anonymous workers. The Reform Act, in theory if not in fact, ended abruptly the tory's almost continuous hold on power for the past half

North. "Before $1850 \ldots$ social movements were greatly affected by catastrophic and simultaneous increases in misery for most of the working population..." E. J. Hobsbawm, "Economic Fluctuations and some Social Movements since 1800 ", in: Economic History Review, 2nd set., V, 1: 1952, p. 5. On p. 6, Hobsbawm presents a chart indicating the seasonality of unrest in Britain from I800-I 850 and indicates that in early June-Nov. 1837 , coinciding with Anti-Poor Law campaigns and again May-June, 1839 , coinciding with Chartism, there is clear relation of economic distress and the growth of both Anti-Poor Law and Chartist sentiment. Cf. Mather, Public Order in the Age of the Chartists, especially p. 16.

1 Cooke Taylor, Notes of a Tour in the Manufacturing Districts, p. 68.

2 Ibid., pp. 3 I 5 ff.

3 W. J. Linton, "Who Were the Chartists?", in: Century Magazine (New York, Jan. I882), p. 430 .

4 Annual Register (London, 1839). 
century. Dislodged by a union of Whig aristocrats and middle class magnates, tories discovered that length of political tenure was not sufficient grounds for continued power.

In addition theories of political economy questioned the tories' economic function and accused them of being "parasitic" country men. The political economists, developing an argument which industrial interests rapidly adopted, attacked the gentry as a group which did not contribute to national life. The economists argued that the nation would benefit if the power centers were shifted from land to industry, from the traditional paternalism and parochialism of the local gentry to the individualistic and centralized rule of an efficient, rootless bureaucracy clearing the way for mechanistic progress.

Tories could not admit that their tole as a patriarchical country gentry was superfluous in the changing society nor could they welcome the direction of that change. ${ }^{1}$ Northern tories, without economic interests in industrialization, developed a defensive social reform ideology partly as an expedient to attack the middle classes in the vulnerable area of their pocket, but more out of sympathy with the insecurity and isolation of the working man. ${ }^{2}$

Tories were not the only social reformers in the North. Many radicals, liberals and whigs pled working class causes. These reformers were generally philanthropists and humanitarians but unlike the tories they were not social philosophers intent on rationalizing their way of life. Unlike the tories, they recognized and welcomed the permanency of the factory system. But they were prepared to modify its operation to help the worker help himself.

In Lancashire, the M.P.'s who did most for factory reform were either Liberals or Radicals. ${ }^{3}$ The national leadership of factory reform had been assumed from I 833 by the tory paternalist, Antony Ashley Cooper, seventh Earl of Shaftesbury. But it was two Radicals, Joseph Brotherton and John Fielden, who guided Ashley's Ten Hours Bill through its passage. Both were practical manufacturers supporting factory reform on humanitarian grounds. Moreover, both knew from

1 Driver, in Tory Radical, p. 436, summarizes "The Faith of a Tory" through Oastler's rejection of the hungry forties as "the result of frecr trade, of unrestrained capitalism: ... of letting industry and commerce usurp the primacy that belongs to agriculture".

3 Ashley, active in factory and other social reforms, wrote in his Diary on August 24, 1840 , "I have advanced the cause, done individual justice, anticipated many calamities... and soothed, I hope, many angry Chartists' spirits by showing them that men of rank and property can, and do, care for the rights and feelings of their brethren." Quoted in E. Hodder, The Life and Works of the Seventh Earl of Shaftesbury (London, 1886), I, p. 301. 3 But in spite of the efforts of Liberals to encourage working class independence, lack of class consciousness and deference to social superiors continued to characterize Lancashire workingmen up to the I860's. See I. Jennings, Party Politics (Cambridge, 1959), I, p. 329 . 
experiments with shorter working hours in their own factories that the prosperity of cotton manufacturers would not be threatened by legislation restricting working hours. When Fielden moved the second reading of the Ten Hours Bill on April 29, I846, he spoke as a cotton manufacturer with a "great and increasing interest" in the prosperity of cotton manufacture who had "long concluded that the Bill ought to pass, because humanity requires it". ${ }^{1}$

Many middle class observers, not themselves manufacturers, were as aware of working class distress as the tories, or the worker himself. Writers like Cooke Taylor documented the worker's predicament and effectively publicized his misery, but insisted that progressive and irrevocable change had occurred in British life. These social reformers were unacceptable to the unskilled worker because he could not admit the permanency of change from an idealized rural past. As a consumer the unskilled worker obtained few benefits from the industrial system. ${ }^{2}$

Chartist leaders with political ends like William Lovett and the London centered Working Men's Association, failed to influence Chartism in Lancashire and Yorkshire because they, like the middle class social reformers, thought and spoke in metaphors of industrial progress not credible to unskilled workers who continued to think with a peasant's mentality. Middle class Radicals like Joseph Sturge who saw the gap between themselves and the Chartist rank and file and attempted to close it, were not able to persuade unskilled Northern workers to accept middle class leadership for political reform ends. ${ }^{3}$

1 Hansard, 3rd series, LXXXV, p. 1226.

2 MacAskill, "The Chartist Land Plan", in: Chartist Studies, p. 307.

s The Birmingham Radical Quaker, Jos. Sturge, and his Complete Suffrage Union, attempted a "reconciliation between the working classes and those who move in a sphere above them". Manchester correspondent, Dec. Is, I84I, in Nonconformist (London Dissenting weekly edited by Sturge's friend, Edw. Miall), reporting Sturge's appeal to Anti-Corn Law League in Manchester to take up political reform. Sturge, himself, had published an open letter to Cobden asking for reconciliation in the Nonconformist, Sept. 29, I84I. On Nov. 17, I84I Sturge wrote the Nonconformist leader requesting the AntiCorn Law League to secure the "enthusiastic support of the labouring millions" by "seizing upon the banner of COMPLETE SUFFRAGE" to effect a union "between the now divided sections of society". By March, 1842 there were so or 60 Complete Suffrage Unions in the course of formation throughout England. Hovell, The Chartist Movement (Manchester, 1925), p. 244. In May, 1842, Sturge contested Nottingham at a by-election and ran (on a Chartist-Quaker-Free Trade platform) against the Tory organic theorist John Walter, editor of the Times. Stephens supported Walter and O'Connor, in one of his occasional attempts at middle class alliance, supported Sturge. Walter polled i 885 votes and Sturge 1801 . See West, 180 and Read and Glasgow, I02. By 1842, the C.S.U. had failed. See Briggs, Age of Improvement (New York, 1959), pp. 32 of. Lovett attributed part of the failure of the local C.S.U. movement to the aloofness of great "numbers of the working classes" guided by "the abuse and misrepresentations of the Northern Star". Life and Struggles (London, 1876), p. 275 . 
Radicals urged Northern Chartists to make political reform respectable by disavowing physical force, but they failed. ${ }^{1}$

O'Connor himself failed when he encouraged a middle and working class alliance on three occasions in 1842,1844 and the latter part of I 848.2 And it is significant that he always had more followers when he abused the Whigs and middle classes, as in 1839,1842 and the spring of 1848 , than when he encouraged unity. O'Connor destroyed these short-live alliances with middle class leaders when he discovered that they weakened his autority over the Northern workers. It may be argued that in large part O'Connor's popularity was directly proportional to his attacks on the middle classes.

O'Connor was able to lead the Northern Chartist movement while class-conscious leaders like William Lovett failed, because O'Connor understood and shared the Northern worker's nostalgia for a simpler past. The political leaders, on the other hand, misunderstood the psychology of the unskilled worker, his economic strength, and his readiness for common action. ${ }^{3}$

Lovett, through the 'thirties, and Bronterre O'Brien, through the 'forties, insisted to O'Connor that the Chartists were united and did not have to be "led". In I 838 , Lovett attacked "the Oastlers and the O'Connors" for their paternalism and asserted that the Chartists had "disclaimed leadership of every description." 4 He believed that working men were concerned with political principles, devised for themselves in their own best interests, and not in "public idols". ${ }^{5}$ While Lovett may have described O'Connor accurately as "the great

1 In 1848 , the Chartist P. Aiken complained that earlier middle class sympathy for the Chartists had been alienated by extremists who had driven middle class reformers out of Chartist ranks. The People's Charter (London, 1848).

${ }_{2}$ This is hardly surprising since many middle class reform organizations appeared to be more concerned with the morality of the laborer than with his social and economic condition. In Manchester the Statistical Society, formed by a group of bankers, cotton manufacturers and clergymen "to assist in promoting the progress of social improvement in the manufacturing population by which they are surrounded", took the position that the Factory Act of 1833 was unnecessary. T. S. Ashton, Economic and Social Investigations in Manchester, I833-1933 (London, 1934), p. I 3 ff. Although Dr. Kay (later KayShuttleworth) of Manchester had written a sympathetic report on workingmen's wretchedness in 1832 , by 1834 he was an Assistant Poor Law Commissioner in Manchester painting an attractive picture of these same conditions.

${ }^{3}$ In the Trades Journal of Mar. I, I841, the editor recalled that in the meetings of the G.N.C.T.U., whenever obstacles arose, workmen "chose to turn back, each taking his own path, regardless of the safety or the interests of his neighbor. It was painful to see the deep mortification of the generals and leaders of this quickly inflated army, when left deserted and alone upon the field." Quoted in the Webb's History of Trade Unionism, 2nd ed. (New York, r920), p. 153.

- Lovett, Life and Struggles (New York, I920), I, p. 199.

s Ibid., I, p. I65. 
I AM of politics", 1 he failed to see that unskilled Chartists in Yorkshire and Lancashire preferred leadership from above, if directed towards social and economic gains, to the egalitarian principles of the London radicals. ${ }^{2}$

The class conscious leaders also misjudged the Chartist's ability to use economic pressure to achieve their ends. When the delegates to the Chartist Convention assembled in I 839 , this "sober, black-coated, middle-aged body" adopted economic measures to coerce Parliament into passing the Charter. ${ }^{3}$ But the Northern Chartist could not carry out any of these measures. A general strike and the withdrawal of savings from banks were impossible for the great numbers of Chartists who had only the most precarious conditions of employment and no savings at all. ${ }^{4}$

Perhaps the most untenable assumption of Radical Chartist leaders was that Chartists were prepared to act together. Even in times of common distress, the unskilled laborer did not recognize his problems as the common problems of an economic group and rarely identified with fellow workers. The wholesale arrest of Chartists in the summer of 1839 provoked little response among the Chartist rank and file who remained free. Defence appeals were almost unanswered. During the $1830^{\circ} \mathrm{s}$ and 40's, the Northern Chartist did not seek the cure to economic insecurity in union with his fellows, but in personal wage increases. ${ }^{5}$

1 Ibid., I, p. 166.

2 Lord Ashley confided to his Diary on Aug. 18, 1842, that the Chartists of Leeds had told him, "had we a few more to speak to us as you have done, we should never again think of the Charter." Quoted in Hodder, Life and Work of the Seventh Earl of Shaftesbury, I, Pp. 433 f.

3 Hovell, quoting from the Northern Star, Nov. 2, 1839 , in The Chartist Movement, p. I23. On the whole the delegates from the B.P.U. were middle class men. Of the 53 delegates only 24 were "working class". Cf. West, History of Chartism, p. 107, quoting from the Place Mss (27, 82I, fo. r43.) Place used Lovett's monthly report on the attendances for March.

4 At Birmingham, the appeal to arms took second place to an appeal to economic weapons, were the Charter to be rejected. Hovell, The Chartist Movement, p. 149. Cf. D. Williams, John Frost (Cardiff, 1939), p. I 66 for discussion of the "ulterior measures" proposed. These included withdrawal of all savings from banks; conversion of all paper money into gold; a sober general strike; and, trading exclusively with pro-Chartist tradesmen. In the Northeast, one of the fundamental factors against an attempted "Sacred Month" was that most workmen there "were too comfortable to want to strike". Maehl, "Chartist Disturbances in Northeastern England, 1839", p. 413.

s J. A. Roebuck, Radical author of the preamble to the Charter, accused the Chartist rank and file of sacrificing political reform to have wages fixed. Letter to Dr. R. Black, April I6, I848, in R. E. Leader, Life of J. A. Roebuck (London, I897), p. 204. 
The Northern worker's inability to adjust to industrial conditions explains only part of his receptivity to paternal theory. He was as much attracted to the security of an ordered, if hierarchical society, as he was repelled by the laissez-faire implications of an industrial society, free but precarious. ${ }^{1}$ The tory paternalist promised working men that the harmonious order of the rural past could be revived to mitigate the insecurity of the urban present. And, like the unskilled worker, the tory reformer idealized an agrarian life as the good life.

The Northern tory urged workers to follow him away from the laissez-faire individualism of the middle class. ${ }^{2} \mathrm{He}$ rejected liberalism because it asserted unlimited progress and simplified human nature contrary to all religious and historical evidence. 'To the tory theorist, human nature was not a product of economic self-interest. Man was rather a complex ethical and social being, dependent for direction on the communal guidance of family, church and society. Progress was limited by the traditions of the past and by providential design. Although pessimistic about human nature, the Northern tory accepted the reality of change and argued that unless guided by social planning, change would not be ameliorative. He recognized that local action could not meet national problems effectively and insisted that Parliament must intervene to assure that the stronger did not prosper at the expense of the weaker. ${ }^{3}$

The rapidly changing conditions of British life dismayed the Northern tory because he saw them compounding the natural weakness of men, their irrationality, helplessness and dependence. To combat these conditions the Northern tory reformers became missionaries to the lower classes preaching a millenium rooted in social

1 Roebuck explained that his inability to lead political reform was due to his "political economical notions" which "run so thoroughly counter to the vain visions of many of the workmen, that they would look upon me with distrust" (ibid.). And, Sir George Head, enthusiastic admirer of the Northern factory system, who romanticized the Leeds factory worker (his features "blackened by smoke, yet radiant with the light of intelligence"), argued that "although particular classes of men have suffered by the substitution of machinery for manual labor, such evils arise from the mutability of human affairs, - are such as the most zealous philanthropist cannot avert..." A Home Tour Through the Manufacturing Districts of England in Summer of 1835 (London, 1836), p. 188.

2 Driver, Tory Radical, p. 204.

s When Hobhouse's factory bill was defeated in 1831 , Oastler wrote to Hobhouse that he "exceedingly regret(ed) you felt yourself obliged to yield the sacred cause of the poor to the 'cold, calculating, but mistaken Scotch philosophers'... I wish you had manfully met those unfeeling misanthropes (whose God is money, and whose policy is the ruin, degradation and banishment of the poor) by sound philosophical and Christian argument." Nov. 19, 1831, quoted in S. Kydd, History of the Factory Movement (London, 1857), I, p. 14I. 
harmony. To a man these tories were evangelicals, Anglican and Methodist, whose moral code came from their religious conscience. ${ }^{1}$ Unable to accept a morality glorifying individual success instead of social harmony, they emphasized Burke's dictum that social status and social responsibilities were inseparable. ${ }^{2}$

To persuade the Northern worker of the tory's fitness as a leader of workingmen's causes, the Northern tory identified toryism with social welfare. Richard Oastler, accepted by his working class following as the "Factory King", denied the need for political change but cried out for social reform. ${ }^{3} \mathrm{~A}$ true tory, he wrote in a typical passage, knew that

"each order of society is mutually dependent on the other for peace and prosperity, and that although there are many members, yet there is but one body. And the eyes cannot say unto the hand, I have no need of you. Nay, much more, the members of the body which seem to be more feeble are necessary."4

The other Northern tories justified themselves to the workers by arguments so nearly identical in tone and metaphor to Oastler that they are often indistinguishable from each other. In the speeches of Sadler, Stephens and Bull, too, the principal image is of a body politic, organically harmonious under God, to be restored through the humane agency of tories. ${ }^{5}$

1 Parson Bull wrote in his first editorial for the British Labourer's Protector and Factory Child's Friend, 1832, "Our principle is, that whatever benefits the labouring classes benefits the whole community, that no nation is blessed of God or prospers, in itself, where they are depressed." Quoted in J. C. Gill, The Ten Hours Parson (London, 1959), p. I 25. Michael Sadler's attempted refutation of Malthusian theory was based upon his belief in a "kind and superintending Providence". Law of Population (London, 1830), I, p. 25. During his conduct of the famous Select Committee in $183 \mathrm{I}$, Sadler, seriously ill, worked day and night to muster evidence for factory reform: "This is God's work in which I am engaged, and therefore it must be done." Kydd, History of the Factory Movement, I, p. 3 I6. Cf. Driver, Tory Radical, p. 170.

2 The first two of Oastler's four mottos heading his weekly Fleet Papers and symbolizing his social principles were: "The Altar, the Throne and the Cottage" and "Property has its Duties as well as its Rights". Driver, Tory Radical, p. 416.

3 When Oastler was interviewed by the Manchester Radical Association to determine his views on political reform, he said, "My opinion on 'Universal Suffrage', is that if it were the law of the land next week, it would in a short time produce 'universal confusion' and would lead inevitably to despotism." Twopenny Dispatch, quoted in Kydd, History of the Factory Movement, II, p. 84. Oastler's rejection of political reform, shared by Sadler Bull and Stephens, in no way impaired the popularity of the "Tory Democrats" in the North.

- Quoted in Driver, Tory Radical, p. 428.

- See especially M. T. Sadler, Law of Population, I, p. 17; Bull's Speech at Manor Courthouse, Manchester, April I, I833, in Kydd, History of the Factory Movement, II, p. 29ff.; and J. R. Stephens' New Year Address at Ashton-under-Lynne, I839, quoted in Ibid., p. 99. 
The Northern paternalists, with the single exception of Feargus O'Connor, wanted to give the worker social and economic security but not political rights. ${ }^{1}$ In politics, they wanted to provide tories with a better claim to national power than Eldon-Wellingtonian repression or Peelite expediency. Radical Chartists knew that the social and economic promises of Oastler and his friends could not guarantee the worker real security unless accompanied by political reform: "It is true that there was a thin party of the school of Oastler, but their claims on behalf of labour were those of benevolence rather than of fundamental right."2

Chartist leaders who agreed upon little else did admit the residue of strong working class feelings of respect for the gentry. A typical radical complaint was that workers "liked to be led by gentlemen. They had no distrust of their social superiors; on the contrary, trusting them far more than their own brethern... They think a gentleman has nothing to gain and give him credit for perfect disinterestedness."3 Many Chartists tried to counter working class susceptibility to the claims of tory paternalism. George Julian Harney thought that he could prevent Chartists from believing the promises of tory paternalists by exposing the feudalistic assumptions in their thought. When literary editor of the Northern Star in 1844, Harney printed long extracts of Disraeli's Coningsby to warn his readers of the lack of reality in the Young England solutions. ${ }^{4}$

Despite the attempts of Harney and Lovett to compel Chartists to become independent, other Chartist leaders increased the authority of their leadership among laborers by presenting themselves as "gentlemen". Although Chartist leaders generally did not tend to defer to the gentry, three of the most popular leaders, Ernest Jones, ${ }^{5}$ John Frost, ${ }^{6}$ and particularly Feargus O'Connor, maintained their class distinction because it gave them additional prestige among their following. While these three cases do not prove Chartist deference to the gentry, they do reveal ambiguous and transitional working class attitudes, vacillating from resentful and implacable hostility towards privilege to romantic nostalgia: "An aristocrat," Gammage wrote reluctantly," is

1 See p. 446 , note I.

2 R. G. Gammage, History of the Chartist Movement(London, 1 843), p. 75. Later editions of Gammage present a less negative opinion of Oastler.

3 J. A. Roebuck, quoted in Leader, Life of Roebuck, pp. 354 f.

- The Northern Star, Nov. 9 and Dec. 14, 1844; and Feb. 14, 1845.

${ }^{5}$ Gammage believed that Chartist enthusiasm for Jones was due to his superior social origins. History of the Chartist Movement, p. 282.

- D. Williams argues that Frost, leader of the Newport Chartists, had great prestige among his followers because he was a gentleman who took care to sign "Esquire" after his name. John Frost, Pp. 81-86. 
always most acceptable to the working classes, even to Democrats."1

Working class ambiguity towards the upper-classes is even more apparent in the support given by the unskilled Northerners to Feargus O'Connor. ${ }^{2}$ O'Connor described himself as a radical but he never let his followers forget either his high birth or his proprietary interest in the land. By background, temperament and social theory O'Connor was gentry, and by 1838 he was also unchallenged leader of Northern Chartism. His attacks upon the middle classes were based as much upon their parvenu status as the "new families" as upon their injustice to the worker. ${ }^{3}$ When he began Chartist land settlements, O'Connor urged landed gentry like Lord Wriothesley Russell to interest himself in the settlers because Chartists "liked to be noticed by people of rank". And, in one of the few moments of truth he permitted himself, O'Connor confided to Russell's brother Charles, "collectively they [the working classes] are with me but individually they are with you.",

\section{III}

Workingmen's attitudes towards the tories as a social class were based on nostalgic memories of gentry fulfilling patriarchical responsibilities. Sentimental about gentry in the rural past, the unskilled urban worker wanted present proof of the tory's desire and ability to provide greater benefits than those promised by the industrial system. In the early I 830 's, tories in the north became active conspicuously in factory reform and Anti-Poor Law movements. This advocacy of working class causes was the paternalistic tory's specific response to any working man's scepticism about tory willingness to act effectively for the lower classes. By 1850 , attempts to solve problems of industrial displacement through paternalism petered out into agrarian utopianism, an escape from those problems.

Before the tory paternalist turned away completely from industrial society, he convinced many workmen in Lancashire and Yorkshire that "toryism" was a class commitment to improve the "condition of England". Evidence for workingmen's faith in tory leaders is best

1 Gammage, History of the Chartist Movement, p. 282.

${ }^{2}$ From April, I 838, Feargus O'Connor became the "Apostle of the North, the constant travelling dominant leader", Place, Add. Mss., 27, 820, fo. I35, quoted in Read and Glasgow, Feargus O'Connor, p. 55 .

"O'Connor was pleased that he, a member of the "old" families, had been elected to Commons in 1834 over the usurping middle classes. Gazette, Jan. 31, 1835, in Tbid.

- Aug. 8, 1848, quoted in Greville, Memoirs, II, p. $34^{2}$. 
supplied by their enthusiastic acceptance of such tory paternalists as Richard Oastler, Joseph Raynor Stephens, Michael Sadler, and Parson Bull. The only Radical completely accepted in Lancashire and Yorkshire was Feargus O'Connor, who was as much a tory paternalist as a Radical. ${ }^{1}$ Tory activities in the North were ignored by the formal Tory or Conservative parties but were supported nationally and locally by many tories in journalism, literature, local institutions and organizations, and, occasionally, in Parliament.

Beginning with combination and continuing through factory reform and the Anti-Poor Law crusade, tory journalists presented the worker's grievances to a national audience. In opposition to the prevalent fear that unions were incompatible with public order, the tory Leeds Intelligencer had endorsed the worker's rights to combine. And in the election of 1834 , the Intelligencer supported the candidate openly accepting combination, Sir John Beckett. ${ }^{2}$ Although the Intelligencer's motives in occasionally supporting working class unions may have been simply harrassment of the industrial middle classes, it took a position most welcome to workers.

Other influential tory journalists criticized their party for failing to respond constructively to the unfortunate consequences of industrialization. Gifford, editor of the Standard, was an early supporter of Shaftesbury and a pronounced opponent of the New Poor Law of $1834 .^{3}$ Even the editor of the orthodox Quarterly, Lockhart, became preoccupied with the "condition of England". In a letter to Croker, Lockhart insisted that the only question which really concerned him was the "improvement of the condition moral and physical of the people". And he added, "I fancy most men of my tendency who are not immediately engaged in politics are of much the same mind."4

Lockhart's conjecture, not true of the great majority of tories, did apply to the most powerful and influential organ of tory opinion, the London Times. The most sustained newspaper attack on working class problems, outside of O'Connor's Northern Star, was carried out by the Times. John Walter, editor of the Times, held the same organic, paternal view of social relations as the Northern tory reformers. After earlier support for factory reform, Walter launched a long editorial

1 O'Connor, who by all natural inclinations leaned strongly towards tory paternalism, believed in suffrage extension. On this point alone, he differed from the romantic tory notion of a patriarchical social order.

2 R. L. Hill, Toryism and the People (London, 1929), p. I 22.

3 R. B. McDowell, British Conservatism, 1832-1914 (London, 1959), p. 33.

- Quoted in Tbid., p. 32. That Lockhart was partially correct is seen by the activities of Rand and Walker, tory manufacturers from Bradford who urged on Peel and Graham the importance of factory reform. See Kitson Clark, "Hunger and Politics, I 842", in: Journal of Modern History, XXV, 4, Dec. 1953, p. 361 . 
crusade against the new Poor Law Bill on April 30, 1834, with a typical tory protest against centralized power and the theories of political economy which lay behind the Bill. By May 3, his major criticisms of the Bill took the form of a paternalistic defense of "the rights of the people - particularly the most defenceless of them - the poor". 1

The arguments of professional journalists for tory led social reform were echoed by a variety of tory pamphlets in the 'thirties and 'forties. ${ }^{2}$ These pamphleteers were not a unified group holding consistent attitudes toward social, economic or political problems. But, in common with tory journalists and local organizations, they believed that "toryism", the landed interest, best represented the national welfare. This conviction was emphasized by Croker, perhaps the best gauge of solid tory opinion during these years, when be condemned Peel's repeal of the Corn Laws as an attack upon the "territorial influence" which gave England stability and continuity. ${ }^{3}$

Like Croker, many tory pamphlet writers saw "toryism" as "neither more nor less than the Spirit of the British Constitution". 4 The "real tory," a typical apologist wrote, would always act for "the welfare of the British people".5 "Toryism" or "conservative principles" meant a "high and solemn trust for the good of the people at large". 6 The occasional pamphlet writers insisted that the only moral society was one which vested political power in the land. ${ }^{7}$ In common, the tory pamphleteers

1 Walter's leaders through the following months repeated the argument that the state ought to care for the poor. But, alongside of his Anti-Poor Law campaign, Walter conducted an offensive first against the journeymen tailors who had struck in London, and then against the Trades Union movement in general. It is significant that this attack upon trade unions did not apparently impair Walter's popularity with Northern workingmen. The Times, May-Aug., 1834.

2 Typical pamphlets include: Rev. S. Demainbray's The Poor Man's Best Friend, a letter to the Marquis of Salisbury (1831); J. Wood's Right of Labour to Legislative Protection (1832); Anon., The State and Prospects of Toryism (Jan. 1834); Wm. Blacker's The Claims of Landed Interests to Legislative Protection Considered (London, 1836); H. Drummond's On the Attempted Government of the Queen and Attempted Government from the People (London, 1842); G. W. Lewis' The Conservative Principle Considered in Reference to the Present State of the Country (London, I842); and J. M. Morgan's The Christian Commonwealth, (1845).

Quarterly Review, LXXXI, p. 308.

4 "The State and Prospects of Toryism" (Jan. 1834, reprinted from Fraser's Magazine), p. 17. In Special Collections, University of California, Los Angeles.

Ibid., p. 23.

- G. W. Lewis, The Conservative Principle Considered in Reference to the Present State of the Country (London, 1842), p. 35. Special Collections, University of California, Los Angeles.

'H. Drummond, On the Attempted Government of the Queen and Attempted Government from the People (London, 1842). 
believed that they knew better how to provide for the needs of "the people" than they did themselves. ${ }^{1}$ And, by the end of the Chartist period, there was at least one early draft of Disraeli's famous omnias sanitas or social welfare speech promising that Conservative policy would

"exert itself to advance all those social reforms which are of far more importance than any political reforms. It will endeavour to improve the condition of the poor by measures to promote health, to give them better food, and more air, and light, and water and rational amusements."'

For the reading public, the social "toryism" of the journalists and pamphleteers was echoed in Thomas Carlyle's essays and Benjamin Disraeli's novels. The damning rhetoric of Carlyle's Chartism (1 839) and Past and Present ( 1843 ) attributed working class misery to middle class irresponsibility. Then in 1844 , Disraeli published Coningsby to dramatize Conservative and Whig unwillingness to deal with working class problems. This was followed in 1845 by Sybil or the Two Nations, an appeal for socially responsible "toryism". Disraeli's best sellers were based on documentary evidence of workers exploited by an industrial society and they reached a wide audience. ${ }^{3}$

In the country, tory dominated organizations were formed to carry out locally the program urged by the tory publicists. Among these organizations was the Central National Association, formed in 1837 by James Barnard, a Cambridgeshire farmer and currency reformer to ally the agricultural interests and the working classes. The Central National Association proposed repeal of the New Poor Law, an eight hour factory day, government protection for agriculture and industry, and currency inflation. In April, 1837, Barnard rescued the London Mercury from bankruptcy and so acquired an organ to publicize his views. The Radical Chartist leader, Bronterre O'Brien, then still acting in support of Feargus O'Connor, became joint editor of the

1 See, for example, a review of John Minter Morgan's proposal for a Church of England agricultural settlement based upon principles of social harmony, which criticizes Morgan for his "fancying" that he knew better than the people. Illustrated London News, 24 Aug. I 8 50, Vol, 17, p. 177.

2 Ed. Wm. Cox, Conservative Principles and Conservative Policy: A Letter to the Electors of Tewkesbury (London, I 852), p. II. Special Collections, University of California, Los Angeles.

${ }^{3}$ B. Disraeli, Sybil (London, 1913), pp. 488f. Disraeli's novels were more effective than his attempts to produce a political party of Tory paternalists which he called "Young England". Their parliamentary record testifics to the vagueness of their principles and to their ineptitude. The shrewd old Chartist, W. J. Linton, writing many years later, characterized Young England as "dreamily benevolent Conservatism (Carlyle interpreted by Benjamin Disraeli...)", Linton, "Who Were the Chartists", in: Century Magazine (New York, 1882 ), p. 423. 
Mercury and the paper was endorsed by the Chartist East London Democratic Association, the London group following O'Connor's leadership. ${ }^{1}$ Although the Mercury floundered eventually, it bore witness that there were landed tories prepared to underweite working class causes.

While tory writers and local organizations appealed for national remedies to workingmen's problems, tory magistrates, particularly in the West Riding, tacitly tolerated local demonstrations. ${ }^{2}$ The tory magistrate, not necessarily an advocate of social reform, hated manufacturers. This made him reluctant to curb factory reform meetings and Anti-Poor Law riots. Open sympathy was shown during the Plug Plot disturbances of 1842 because many tory magistrates believed that Anti-Corn Law League manufacturers had encouraged their men to strike in order to embarrass the Tory Government. ${ }^{\mathbf{3}}$ Magisterial leniency was more an attack upon the industrial middle classes than an endorsement of working class grievances. Still, the Northern worker could contrast the tory magistrate's moderation, whatever its motive to the long list of grievances associated with Whig Governments and middle class interests. ${ }^{4}$

In Yorkshire and Lancashire, the Short Time Committees, the heart of the factory reform organization were workingmen's groups often managed by local tory leaders. Parson Bull was Secretary of the Lancashire Short Time Committee while Oastler and Stephens led local organizations in Yorkshire. Oastler probably did more than any other individual to force the issue of factory reform upon Parliament, and Michael Sadler's Parliamentary inquiry documented the

\footnotetext{
1 A. R. Schoyen, The Chartist Challenge (London, 1958), pp. 17 f.

2 On June 5, 1835 a crowd stormed the Poor Law Guardian's meeting in Huddersfield and sacked the workhouse. Tory magistrates refused to summon troops and Oastler's influence alone saved William Swaine, the Liberal chairman, from being assaulted. Ward, The Factory Movement, p. I 8o. And General Sir Charles Napier, appointed to the Northern Command on April, r839, was openly sympathetic to Chartism and hostile to manufacturers who he said produced "corrupt morals, bad health, uncertain wages". Quoted in R. Lawrence, Charles Napier (London, 1952), p. 89. Napier wrote in his journal, "Chartism cannot be stopped, God forbid that it should." And, "Hell may be paved with good intentions but it is hung with Manchester cottons." (p. 90).

3 F. C. Mather, Public Order in the Age of the Chartists, p. 64. In Manchester, "the authorities told the mill owners that they could not be protected if they tried to restart theit mills." G. Kitson Clark, "Hunger and Politics in I842", p. 363.

4 When O'Connor and 58 others were tried at the Lancaster Assizes on March 21, I 843 , the tory Sir Francis Pollack was Attorney General and Counsel for the Crown. Gammage, the politically oriented, anti-Tory Chartist attended the trial, observing that Sir Francis delivered a "very temperate address which contrasted strongly with some of the speeches made by the prosecuting council under the late Whig government". History of the Chartist Movement, p. $23 \mathrm{x}$.
} 
need for reform in spectacular hearings which astonished the nation.

Tory leadership of the Anti-Poor Law movement grew out of factory reform and out of the tory's understanding of the social role traditionally filled by the gentry. Since the Elizabethan Poor Law, the country gentleman had been responsible for administering social welfare in his area. In times of desperate need, the worker had recourse to this patriarchical system of welfare. ${ }^{1}$ Early in the nineteenth century, the traditional poor law system had been endorsed by Cobbett who taught that poor relief was not charity but the worker's customary right. This was endorsed by tories and workers alike. It was rejected by most of the industrial middle class upon the political economist's condemnation of the traditional poor law system as uneconomical and inefficient.

As soon as the Whigs passed the New Poor Law Act of I 834, Tories denounced it for severing the long connection between the gentry and relief administration. In the North, John Walter, Stephens, Oastler and Bull prevented adoption of the new centralized measure for several years after it had been introduced into the South. Tories were not the only opponents of the New Poor Law in the North. Fielden's resistance at Todmorden is famous. But, in the election of I 835, London and Birmingham Radicals concentrated on suffrage extension while Northern Tories made opposition to the New Poor Law the essential part of their campaigns. ${ }^{2}$ Again, in the elections of I 84 I, tory candidates in Yorkshire and Lancashire expressed views "which would not have been unacceptable to Chartists". ${ }^{3}$

Tory championship of factory reform and Poor law repeal in the North cteated national interest but few practical results. Despite frenetic activities through the 'thirties and early 'forties, tory paternalists found that the substance and direction of industrial development was unchanged. Frustrated by failure, tory reformers gave up their efforts to alter industrial life and rejected it entirely for agrarian utopianism.

70,000 Chartists subscribed to O'Connor's land scheme and, in common with discouraged tory reformers, they invested their hope

1 Analysis of the Registrar's returns of 1838 estimated that death and disease among heads of families had thrown 43,000 widows and I 2,000 orphans upon the Poor Law. M. Bruce, The Coming of the Welfare State (London, 196I), p. so. The patriarchal system of welfare idealized by tory social reformers was administered through local control of poor relief.

2 Ward, The Factory Movement, p. 180. When the New Poor Law was installed in the North during 1836 and 1837 , it coincided with severe depression and commercial crisis there which sent unemployed factory workers and handloom weavers to seek relief.

s Kitson Clark, "Hunger and Politics, 1842", p. 360. See Leeds Intelligencer, June-Dec., I 84 I for tory candidates' attacks upon the Poor Law and upon machinery for displacing workers. 
in an agrarian escape from industrialization. Ultimately all the political goals of Chartism were incorporated into the British constitution. But in the late $1840^{\circ}$ 's and early 1850 's Chartism appeared to end in a return to the land movement because other alternatives for achieving immediate reform were closed to the worker one after the other. Handicraft workers turned to the land partially because they depended upon leaders who took this direction. But this dependency was in itself a product of working class failure to achieve solidarity through either trade unionism or political reform. ${ }^{1}$

So long as there was a possibility, however dim, of Parliament's acceptance of the Charter's demands for political reform, the worker could hope that power to remedy his distress would come with suffrage. After the failure of the I 839 petition, many of the skilled Chartists turned to the Anti-Corn Law League but the unskilled were drawn to idealizations of a rural past. Ultimately, the worker's vision of a new society was less significant to him than "the anxious discussion of the old". ${ }^{2}$ To many Northern workers, the only escape from becoming a dispensible cog in a "spinning-jenny, machine kind of nation" was to find a fixed place on the land. ${ }^{3}$

To return to the land meant for many Englishmen, whether workers or aristocracy, a renewal of ancestral strength and security. Even Chartist political leaders, Radicals, and middle class reformers who welcomed industrial progress, 'tended almost schizophrenically to idealize the past which the peasant was losing. ${ }^{4}$ Refusal to accept values to be created by an industrial future is illustrated by the widespread influence of William Cobbett, an agrarian utopian, but one of the first reformers to attract a mass working class following. Bronterre O'Brien, who tried to seize control of the Chartist movement from O'Connor, rejected the middle classes in the name of French Revolutionary principles but was as much influenced by Cobbett as by Robespierre and Babeuf. O'Brien added a pronounced strain of agrarian democracy to his attack upon the middle classes for enriching

${ }^{1}$ Smelser finds that one of the persistent features of the handloom weaver's decline was his attraction to some form of utopianism. Social Change in the Industrial Revolution, p. 253.

2 J.MacAskill, "Chartist Land Plan", in: Chartist Studies, p. 304. See also G. Kitson Clark, "Hunger and Politics in 1842 ", p. 358.

3 B. Disraeli, Speech on Corn Laws, May, 1843 , in Monypenny and Buckle, Life of Benjamin Disraeli (New York, 1912-20) II, p. 142.

- M. Beer, A History of British Socialism (New York, I948), pp. I8-20; J. L. and B. Hammond, The Age of the Chartists (Hampden, Conn., 1930), p. 18. Even Francis Place although a Malthusian supporter of the New Poor Law, supported land nationalization because of the implicit values in life close to the land. See Ward, The Factory Movement, p. 186. 
themselves at the expense of King, aristocracy, Chartists and people. ${ }^{1}$ John Fielden, too, despite his industrial middle class background as a factory owner, was greatly influenced by Cobbett. ${ }^{2}$

Unlike Cobbett, many people admitted the inevitability of industrialization, but tried to perpetuate rural values in spite of it. ${ }^{3}$ Some believed in the myth of a paternal gentry and others assumed, like Cobbett, that the worker had a basic need for roots in the land. 4 Such middle class commentators as Thomas Arnold sought solutions to problems of growing population and working class distress in "park and mansion" and Church. ${ }^{5}$ As late as $184 \mathrm{I}$, this argument was repeated by the middle class Radical Wakely when he told the House that the great landed aristocracy, although they had deserted their post, were the natural leaders of the poor. ${ }^{6}$ The Rochdale Owenites, too, included settlement on estates in their program. ${ }^{7}$

Concrete efforts to meet the worker's supposed need for rural identity were proposed throughout the 'thirties and 'forties by paternalistic "Church and King" tories who wanted to continue the traditional combination of agriculture and small scale industry typical

1 G. D. H. Cole, Chartist Portraits, pp. 239-243.

2 Fielden's Society for National Regeneration was endorsed by Cobbett and included among its aims the teaching of duties "appertaining to Cottage Economy". Herald of the Rights of Industry, Feb. 8, 1834, in Smelser, Social Change in the Industrial Revolution, p. 242.

${ }^{3}$ In correspondence between John Gladstone and Sir Robert Peel on Oct. Is and 25 , I 842 , there is a discussion of the moral, social and even agricultural value of spade husbandry. Both appeared attracted by the concept of allotments and small holdings. Additional Mss, pp. 40, 5 I 7 f. $3_{8-40}$, in Kitson Clark, "Hunger and Politics in 1842 ", p. 359. 4 In 1831 , Stephen Demainbray, Chaplain in Ordinary to the King and Rector of Broad Somerford Wiltshire, published his The Poor Man's Best Friend: Land to Cultivate for his own Benefit (London, 1831), in Special Collections, University of California, Los Angeles. He argued, as Michael Sadler did, for the necessity of making allotments of land available to the working classes. Two years later George Carrington of Great Missenden in Buckinghamshire published an account of his father's division of his estate into allotments for laborers. Carrington's motives were not paternal, but he did have a mystical feeling for the necessity of living close to the land. A Rood of Land, the Labourer's Friend: or, A Short Argument in Favour of Allotments (London, I833), Special Collections, University of California, Los Angeles.

B T. Arnold, "Letters to Sheffield Workers", in: Sheffield Courant, in Miscellaneous Works (New York, I845), p. 433.

- Second Reading of the Poor Law Amendment Bill, Feb. 4, I84I, Hansard, 3rd Ser., LVI, p. 404.

"MacAskill, "Chartist Land Plan", in: Chartist Studies, p. 337. In I847 and 1848, the Steam-Engine Makers suspended some of their branches for depositing branch funds in O'Connor's Land Bank. Two branches of the Stonemason's Society proposed this same investment but were voted down. When Yorkshire Woolstaplers tried to resettle their unemployed on a farm, the only protest came from their younger members, Webbs, History of Trade Unionism, rev. ed. (New York, 1920), p. 178. 
of the pre-industrial small town and village. ${ }^{1}$ In I 83 , Michael Sadler tried unsuccessfully to supplement his crusade for factory reform by sponsoring an Agricultural Bill to provide urban workers with cottages and small plots of land. ${ }^{2}$ And on March 30 , 1843 , William Busfield Ferrand, a tory active in the Ten Hours Movement and the Anti-Poor Law campaign, proposed a Bill for the allotment of waste lands to "restore the poor to their former comforts". ${ }^{3}$ Privately, Ferrand and other tory social reformers put small allotment schemes into operation on their own estates to prove that "an intelligent resident nobility and gentry" was devoted to the "welfare of those under them"."

Feargus O'Connor's program to resettle surplus industrial population was the most ambitious of the return to the land schemes and the most futile. From 1 843, O'Connor tried to persuade his working class following that a small holder system would provide them with greater security than they could achieve through political reform. Through the Land Plan, the worker would escape "the suffering and servitude of the new industrial society". ${ }^{5}$ The 70,000 subscribers who seized the opportunity to escape into the past, came mostly from the small Northern towns with declining industries, which had filled the Chartist movement. The appeal of the land program was much weaker among agricultural workers. Closeness to the land tended to discourage romantic notions of rural life.

When O'Connor diverted his energies from leading Northern

1 MacAskill, "Chartist Land Plan", in: Chartist Studies, p. 304 points to the "paradox" that the 1840 's, "the time of conscious attempts to grapple with the implications of industrialization, should be the decade when questions of land ownership and use were thrust into the foreground."

${ }^{2}$ Hansard, 3rd ser., VIII, pp. 524, 532 ; and Sadler, Memoirs (London, 1842), p.585. John Minter Morgan tried to interest Parliament and the Church of England in a "Church of England Agricultural Self-Supporting Institution", publishing this plan in I 845 as the Christian Commonwealth. In 1850 he tried to raise $£ 50,000$ to erect a "church of England selfsupporting village". G. C. Boase, Dictionary of National Biography (Oxford, I 92 I-22), XXIII, pP. 9I gf. Morgan's Christian Commonwealth was meant to be a socially harmonious community, rigidly excluding the "pernicious principle of competition" characteristic of industrial society. Quoted in Illustrated London News, 24 Aug. I 850 , XVII, p. 178.

3 Quoted in Ward, Factory Movement, p. 257.

- S. Kydd, History of the Factory Movement, II, p. I63. See also Ch. Whibley's account of Young England, Lord John Manners and His Friends, 2 vols. (Edinburgh, 1925). In June, I 844, Ferrand let over Ioo acres, in quarter acre allotments, and Disraeli addressed the new tenants in the metaphor of Tory social theory. Monypenny and Buckle, Life of Disracli, III, p. 248.

s Quoted in Read and Glasgow, Feargus O'Connor, p. x10. O'Connor relied on spade husbandry, a technique derived from an uncle in Ireland and advocated since 1827 by William Cobbett. Ultimately, then, O'Connor's solution for working class problems came back full circle to Cobbett's agtarian idealizations. 
Chartism to proselytizing his land program, he moved still closer to the organic notions of the tory theorists and away from the political program long advocated in the Northern Star. And, he carried the great majority of unskilled Northern Chartists with him. O'Connor's retreat to the Land was opposed by Bronterre O'Brien whose belief in political reform won out finally in 1847 over his earlier agrarian sentiments. O'Brien came to see O'Connor's attraction to a rural panacea as dangerous to both the immediate and long range needs of the industrial worker. With little success, O'Brien used the columns of the National Reformer to encourage working class independence and class consciousness. He warned that "every man who joins these societies is practically enlisting himself against his own order."1 But the unskilled Northern worker understood O'Connor's promises of security on the land better than O'Brien's plea for working class unity.

1 Quoted in W. H. G. Armytage, "The Chartist Land Colonies, 1846-1848", in: Agricultural History, Vol. 32, 1958, pp. 92 and 98. 